\title{
From the Epics to the Second Sophistic, from Hecuba to Aethra, and finally from Troy to Athens: Defining the Position of Quintus Smyrnaeus in his Posthomerica*
}

\author{
PAUL SCHUBERT
}

\section{Introduction}

The aim of this paper will be to explore one aspect of the relationship between two important elements of Greek literature of the Empire, which are on the one hand the influence of Athens, expressed in different ways but mainly through rhetoric, and on the other a tradition which can be associated with the flourishing practice of epic poetry. Rhetoric clearly developed in classical Athens, and has then enjoyed a considerable revival in the so-called Second Sophistic; epic poetry does not take its roots in Athens, but in a broader - and much older - context largely associated with Asia Minor. Both nevertheless seem to meet in the literature of the Empire.

In spite of this apparent convergence at a relatively late date, Athens actually plays a rather marginal role in the tradition of the Trojan War, if we leave aside the famous 'catalogue of ships' in the Iliad, where Menestheus leads the Athenian contingent (Il. 2.546-556). ${ }^{1}$ In anticipation of the following discussion, it is nevertheless worth mentioning that this passage was either used by the Athenians to bolster their claim to leadership, or rejected by the Salaminians when they opposed the Athenians. ${ }^{2}$ It is unnecessary to try to determine the possible intention of the poet in the first place: what matters here is that the venerable text of

\footnotetext{
* I would like to thank Martin Steinrück and André Hurst for their useful suggestions while reading a first draft of this paper. Comments made by the participants of the colloquium were also much appreciated. I remain, however, responsible for all mistakes left in this paper. All translations are mine.

1 For a broad survey of that question, see Latacz (2003b) 175-176.

2 See Herodotus 7.161.3, where the Athenians make use both of Menestheus' mention in the Iliadic catalogue, and of their myth of autochthony. On the Salaminians offering an alternative reading to the text of the Iliad, see Aristoteles, Rhetoric 1.15 (1375b29-30) and Strabo 9.1.10. On a possible Athenian interpolation in the text of the Odyssey, see Schubert (1996b).
} 
the Iliad was subjected to a subsequent reinterpretation by some Greek cities in the Classical period.

When we turn to Quintus Smyrnaeus, we are confronted with an author living in a literary context where rhetoric and epic are constantly intertwined, at least from a formal point of view. I shall thus briefly outline my view on the process which resulted in some poets of the Roman Empire composing Greek hexameters, in the wake of a long tradition. We shall then have to consider the fairly strong link uniting epic and rhetoric during this period. To achieve that purpose, I will focus on the case of a short poem written in hexameters where the influence of rhetoric can be strongly felt. Going beyond the influence of rhetoric on epic poetry of the Empire, I would also like to ask whether there are any signs that Quintus may have integrated some Athenian elements in his narrative, and if so, to what purpose. A full answer to that question would require a detailed study of the whole Posthomerica, which would not fit in the present context. I have therefore chosen to focus on one specific case, that of Aethra, mother of the Athenian hero Theseus. I will also be dealing with her relation to another important character of the Trojan War, Hecuba. This will finally take us to the parallel between Troy and Athens, and to the latter's position towards Rome.

\section{Greek Epic Poetry in the Roman Empire}

Throughout the Classical, Hellenistic and Roman periods, the Iliad and - perhaps to a slightly lesser degree - the Odyssey remained the most influential texts in Greek literature. They provided the background for much writing, singing and painting. Every schoolboy who would later boast of a Greek education had been immersed in their reading. Of course other epic poems were also available, especially at an early period, although they do not seem to have played such a pivotal role in education as the Iliad and the Odyssey. Parts of Hesiod's Catalogue of Women were still read in the Roman period; an abbreviator like Proclus was able to produce, in the fifth century A.D., a summary of the Aethiopis, composed by the archaic poet Arctinus of Miletus. This latter text is of some importance for the study of Quintus Smyrnaeus, since Arctinus covered in five books the first part of the Posthomerica, also corresponding to five books, out of a total of fourteen. ${ }^{3}$

3 For the summary of Arctinus' Aethiopis, see Proclus, Chrestomathia 172 Severyns (= Aethiopis

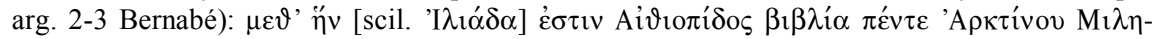

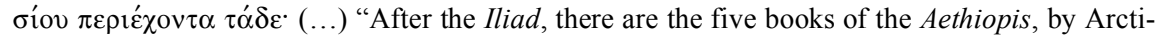
nus of Miletus, with the following contents: (...)" 
Arctinus composed as well a poem on the fall of Troy, the contents of which are to be found in Quintus' book 13. ${ }^{4}$

The predominance of the Iliad and the Odyssey did not prevent poets from producing other astounding masterpieces, like Apollonius Rhodius' Argonautica for instance: this author drew on a tradition possibly older than the Odyssey itself. $^{5}$ Virgil was heavily influenced not only by the Iliad and the Odyssey, but clearly also by the Argonautica, not to mention Athenian tragedy. Apollonius however is not the only poet of his kind, although his poem is the only epic from the Hellenistic period to have been copied throughout the Byzantine period. The recent publication of many fragmentary papyri displaying hexameters, the authorship of which is in most cases not established, shows that the level of poetic activity was in fact higher than one could have suspected a few generations ago. ${ }^{6}$

Greek hexametric poetry never ceases to be practised during the early Roman Empire, but clearly the activity of the Latin poets is much better attested. The Oppians for example, with their didactic poems on fishing and hunting, cannot compete in the same league as Virgil and Lucan. Nevertheless, Greek papyri from Egypt bear witness to the activity of many poets - most of them now anonymous - who wrote hexameters at various levels of competence. ${ }^{7}$ Some authors clearly display a rather clumsy application of the rules of hexametric poetry. A relevant example can be found in a recently published parody of epic found in Kellis, in the Dakhleh Oasis of Egypt. ${ }^{8}$ Additional fragments of varying quality are published at a sustained rate, thus adding to our appreciation of this particular branch of imperial literature. Such is the case with the recent publication of some fragmentary Greek hexameters, copied in the second century A.D., in which an anonymous poet mentions the Dioscuri, the Tiber, and also Italy. ${ }^{9}$ The outline of

$4 \quad$ See Iliupersis (Ilii Excidium) fr. 1-7 Bernabé.

5 See $O d$. 12.70: 'A $\gamma \grave{\omega} \pi \hat{\alpha} \sigma \imath \mu \dot{\lambda} \lambda o v \sigma \alpha$ "[the ship] Argo, sung by all".

6 Powell (1925) 1-89 lists a number of epic poets, most of which are to be dated in the early Hellenistic period. The "epica adespota" (71-89) are relatively scarce. In comparison, the bulk of hexametric "adespota papyracea" collected in Lloyd-Jones / Parsons (1983) 399-458 (n. 900956) reflect the importance of those new fragments in our assessment of the activity of so-called minor epic poets in that period.

7 Those fragments were collected by Heitsch $\left({ }^{2} 1963\right)$ 51-152 (XIV-XLII). Although this work remains indispensable for the study of Greek poetry in the Roman Empire, it is clearly becoming outdated, as some new fragments have appeared in the last four decades. On the question of rating Greek imperial poetry, Gianfranco Agosti has drawn my attention to a passage of Erlich $\left({ }^{2} 1965\right)$ 261: "Literature, the Formalist argued, is not a succession of masterpieces. One cannot understand the evolution of literature or assess any period in its history without taking note of the second- and third-rate. For one thing, masterpieces can be recognized as such only against the background of mediocrity. For another, failure can sometimes be as important a factor in literary dynamics as success."

8 See Hope / Worp (2006), esp. 233-247.

9 PLouvre II 93. 
the story suggests that this poet could have been influenced by Virgil's account of the settlement of the Trojans in Italy. In a more traditional register, there is also a fragment of hexametric poetry on the death of Achilles. ${ }^{10}$

We also know the names of some epic poets who did not leave any significant fragments. Such is the case, for instance, of Nestor of Laranda, who composed a new version of the Iliad in which one letter of the alphabet was missing in each of the twenty-four books. ${ }^{11}$ Scopelianus is recorded both as a rhetor and a poet. ${ }^{12}$ One could name as well Soterichus of Oasis, an epic poet active during the reign of Diocletian, at the end of the third century. A recently published papyrus has been tentatively identified as a portion of his Praise of Diocletian. ${ }^{13}$ One could also mention the four books of his Bassarica, also called Dionysiaca, which were composed in hexameters as well. ${ }^{14}$ More generally, our sources indicate a relatively high level of activity in the realm of epic poetry in Upper Egypt during the Roman Empire, although we cannot exclude some distortion due to the uneven distribution of our sources: poets may have been equally productive in other parts of the Empire, even if they did not leave as many traces as in Egypt. ${ }^{15}$ Thus abundant remains of the activity of poets in the Roman Empire are to be found also in epigraphy, especially in Asia Minor. ${ }^{16}$

10 PKöln X 402 (copied in the second century A.D.), one piece of which was previously published as $P K o ̈ l n$ III 129.

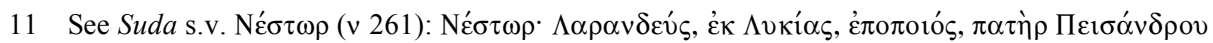

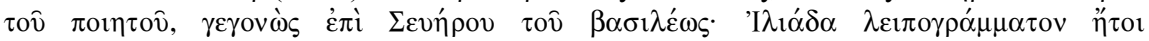

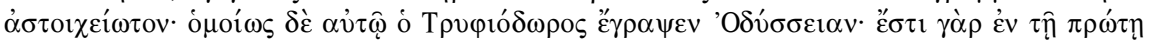

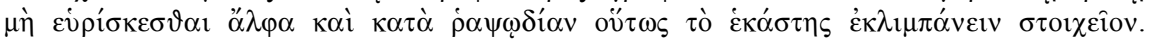
"Nestor, of Laranda, in Lycia, an epic poet, father of the poet Pisandrus, active under the reign of [Septimius] Severus. [He wrote] a lipogrammatic Iliad, that is with one character missing. Tryphiodorus wrote an Odyssey in the same fashion. In the first [book], one does not find [the letter] alpha, and along the whole poem, the letter designating each book is missing."

12 Philostratus, Vitae Sophistarum p. 518 Olearius.

13 See POxy. LXIII 4352; Livrea (1999); Livrea (2002); Braccini (2003).

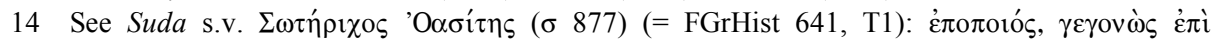

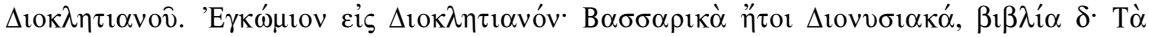

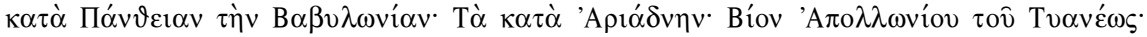

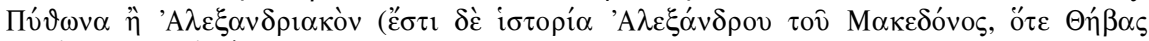

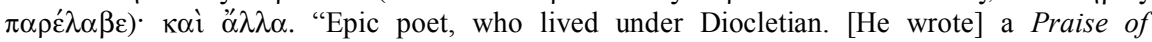
Diocletian; Bassarian or Dionysiac matters, in four books; On Pantheia of Babylon; On Ariadne; a Life of Apollonios of Tyana; Python, or On Alexander (this is a history of the capture of Thebes by Alexander of Macedon); and other works."

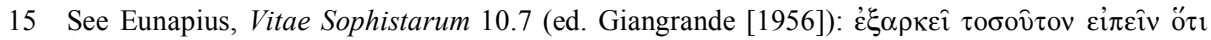

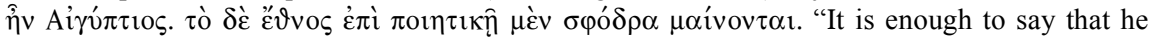
was an Egyptian. Those people are quite mad about poetry." On the so-called 'Panopolitan pole' see Cameron (1982), esp. 217-221; Schubert (2002). On a similar constellation in Middle Egypt known through the testimony of Photius, see Hammerstaedt (1997).

16 For a survey of Greek poetry in the Antonine period with a special emphasis on epigraphy, see Bowie (1990). 
Such is the general setting for hexametric poetry during the early Roman Empire, or in other words during the period that directly precedes the activity of Quintus Smyrnaeus. I follow Ursula Gärtner's recent assessment of the life of Quintus in placing him around the end of the third century, but also in admitting that this is only to be considered as a plausible date. ${ }^{17}$ This would make him a near contemporary of the aforementioned and less celebrated Soterichus of Oasis. In the following decades, we encounter other poets, such as Triphiodorus, whose Iliupersis seems to have borrowed some elements from Quintus. ${ }^{18}$ The Vision of Dorotheus, preserved by a Bodmer Codex, has been dated between the early and late fourth century. ${ }^{19}$ This leads us to firmer ground, with the activity of fifthcentury poets such as the Egyptians Colluthus of Lycopolis, Nonnus of Panopolis and possibly Musaeus.

To sum up, if we consider only the epic poetry which was known to us through the activity of Byzantine copyists, Quintus Smyrnaeus stands relatively isolated, between the towering figures of Apollonius Rhodius on the one hand and of Nonnus on the other. Other epic poets whose works were passed on through the ages are only of marginal importance, and Quintus himself was almost forgotten: Cardinal Bessarion rediscovered a manuscript of this poem only after the fall of Constantinople in 1453. But if we take into account the fragments of papyri which preserve portions of epic poetry in the Roman period, it becomes clear that Quintus may have been surrounded by many other epic poets displaying various degrees of skill. Moreover, papyri as well as inscriptions reflect only a tiny portion of the actual literary production; therefore, what is nowadays available through such sources is presumably only the tip of a huge iceberg.

\section{Rhetoric and Epic}

Although elaborate speeches already appear frequently in archaic poetry, the art of rhetoric was not developed then as it was later in Athens, under the influence of the sophists. For the present purpose, it is important to note that, once it had established its position, rhetoric was not constrained to itself: its effects can be felt in other literary genres, notably tragedy (especially with Euripides), historio-

17 See Gärtner (2005) 26 and James (2004) XVIII-XXI.

18 This idea, although commonly accepted, cannot be held for certain; see Gärtner (2005) 25, and also Dubielzig (1996) 11.

19 See Schubert (2002) 20-21. On the vexed question of the identity of Dorotheos, and of his possible relation to Quintus, see Gärtner (2005) 25-26. 
graphy and philosophy. When we move to the Roman period, the emerging genre of the novel is also heavily influenced by rhetoric. ${ }^{20}$

In the Roman period, however, it becomes sometimes difficult to classify texts according to a strict distribution of literary genres. As a short example of the blurring of the boundaries, one can think of Panteleus' short ethopeia in hexameters, describing the despair of Darius' army when confronted to the Athenian troops at the battle of Marathon. ${ }^{21}$

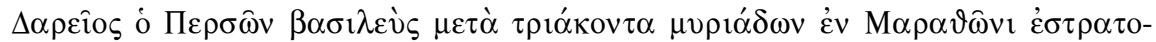

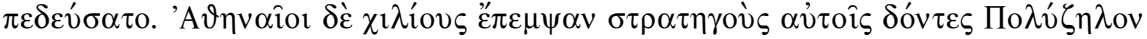

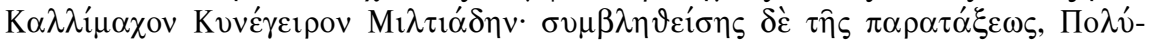

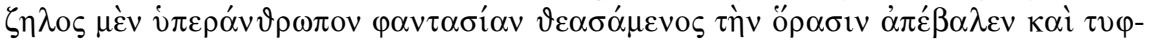

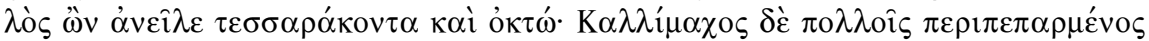

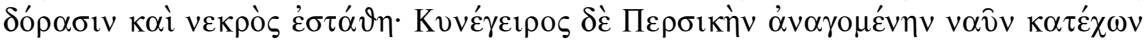

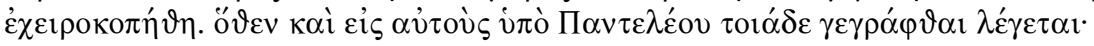

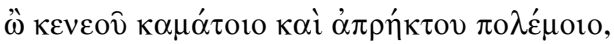

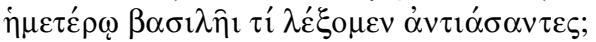

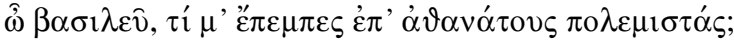

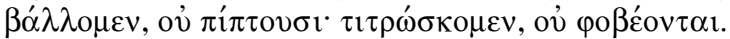

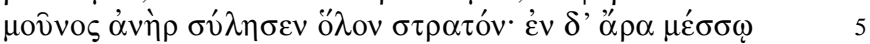

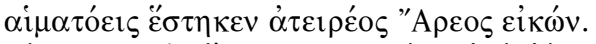

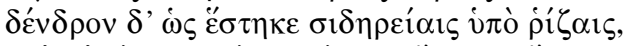

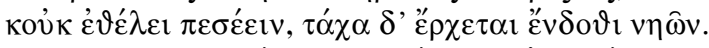

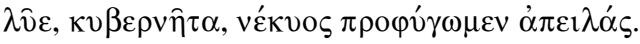

(Panteleus XXIII Heitsch = Stobaeus 3.7.63; ed. Hense [1894])

Darius, king of the Persians, took an army of three hundred thousand men to Marathon. The Athenians, on the other hand, sent a thousand men under the command of the strategi Polyzelus, Callimachus, Cynegeirus and Miltiades. Once the troops had been marshalled, Polyzelus had a supranatural vision and lost his eyesight, and blind though he was, he killed fourty-eight men. Callimachus, although he was pierced by many spears, remained standing even when he was dead. Cynegeirus had his hand cut off while he was holding a departing Persian ship. Therefore it is said that the following verses were written by Panteleus to honour them:

Alas! How vain is the toil, and useless the war!

What shall we say to our king when we meet him?

My king, why did you send me against immortal ennemies?

We hit them, and they fall not; we wound them and they fear not.

A single man has stripped a whole army, and there he stands in the middle,

20 Leaving aside the numerous speeches given in court by various characters, see for instance Laplace (1997).

21 On the spelling 'Panteleus' instead of the commonly accepted 'Panteleius', see D'Ippolito (2002), esp. 227-228. A shorter version of the context can be found - among others - in schol. on Aelius Aristides, Oratio 1.122 (Panathenaic); for a complete list of parallels, see D'Ippolito (2002) 227. 
covered with blood, an untiring likeness of Ares.

He stands like a tree with the help of iron roots,

and does not want to fall, but will soon come into the ships.

Loose the cables, pilot, and let us escape from the threat of a corpse!

This story probably goes back to the more sober account given by Herodotus (6.114), where Callimachus dies in heroic fashion - though he does not remain standing in death - and Cynegeirus has his hand cut off. ${ }^{22} \mathrm{We}$ cannot be sure whether the nine verses stand by themselves, or if they were part of a longer text, for example a praise of Callimachus and Cynegeirus, as has been proposed by Gennaro D'Ippolito ${ }^{23}$.

The sequence of victories over the Persian fleet and army was loudly celebrated by the Athenians and their allies in the decades following the event, as we know from texts such as Aeschylus' Persians, or Timotheus' lyric poem bearing the same title. Simonides composed an elegy on the battle of Platea, a large fragment of which has recently been published. ${ }^{24}$ Panteleus' poem, however, should be dated much later, as it is probably inspired by a speech of Marcus Antonius Polemon (a rhetor of the early second century A.D.), For Callimachus. ${ }^{25}$

The following passage from Polemon shows the closest resemblance with Panteleus' verses.

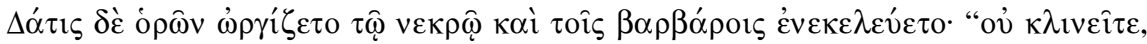

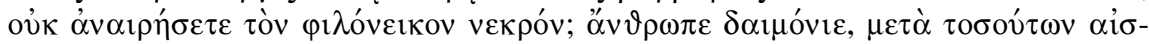

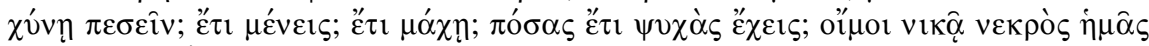

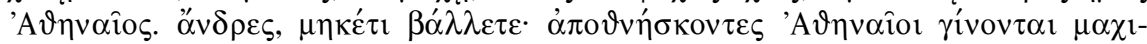

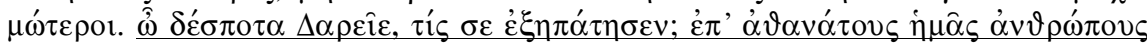

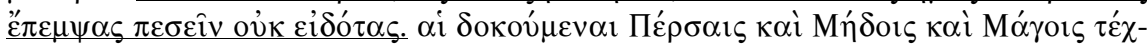

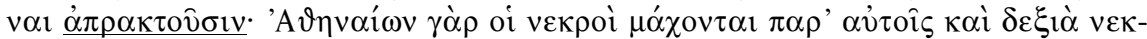

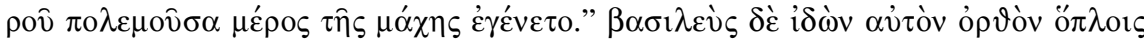

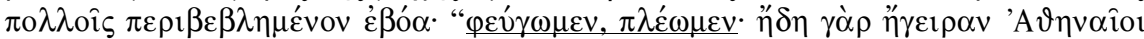

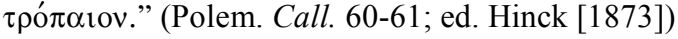

When he saw the [standing] corpse [of Callimachus], Datis was furious and urged on the barbarians: "Will you not turn back this contentious corpse, will you not destroy it? Astounding man, are you ashamed of falling among so many? Are you still

22 The episode of Cynegeirus losing his hand has inspired an anonymous - but nevertheless witty - epigrammatist, see Anthologia Palatina 11.335. It is also found on a sarcophagus of the late third century A.D., see Koch / Sichtermann (1982) 411 and pl. 446; Vanderpool (1966) pl. 35; Harrison (1972) pl. 16.

23 See D'Ippolito (2002) 232.

24 POxy. LIX 3965.

25 See Schmitz (1997) 200-205. The close link between Panteleus' poem and Polemon's speech was already noted by Harrison (1972) 361. A recent edition of Polemon's pair of speeches with a commentary - can be found in Reader (1996). 
staying? Do you still fight? How many lives do you still have? Alas! An Athenian corpse prevails over us! Soldiers, do not throw your spear anymore: when they die, the Athenians become more effective in battle. Darius our master, who has deceived you? You have sent us, mere men, against immortals who do not know how to fall. The established art [of warfare] used by Persians, Medes and Magi does not work: for among the Athenians, their dead keep fighting, and the right hand of a dead soldier took part in the battle!" Then, when the king saw the man standing although pierced by many weapons, he yelled: "Let us flee, let us sail away! For the Athenians have already set up a victory monument." [passages underlined by me]

We cannot precisely date the time when Panteleus was active, but if we accept the idea that he took inspiration from Polemon, we have at least a terminus post quem in the first half of the second century A.D. Although ethopeia in verse becomes more current in the fourth century, it is already attested in school exercises in the early Roman Empire. ${ }^{26}$ At the other end of the scale, Panteleus' verses display a technique where the influence of Nonnus' innovations cannot be found. ${ }^{27}$ This suggests a date before the fifth century, but one cannot completely rule out the possibility that Panteleus, if he had been active after Nonnus, did not follow that poet on the path of innovation. After all, Nonnus' influence was not necessarily radical to the point that every subsequent poet should have adopted the new trends regarding versification. Another argument, however, speaks in favour of placing Panteleus before Nonnus: the latter made use of Panteleus' verses in a Dionysiac battle scene where members of an Athenian troop are killed (Nonn. $D$. 28.113-157); he goes so far as to mention a warrior who loses both arms in the fight but nevertheless keeps on fighting, in imitation of his future countryman, Cynegeirus. ${ }^{28}$ On the whole, I am therefore inclined to think that Panteleus and Quintus belong roughly to the same period.

The brief example provided by Panteleus allows us to stress some important points in order to better understand the context in which Quintus himself composed his epic. The city of Athens had lost much of its prestige during the

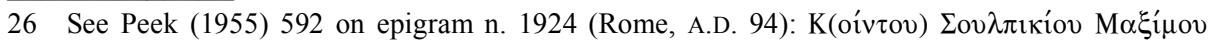

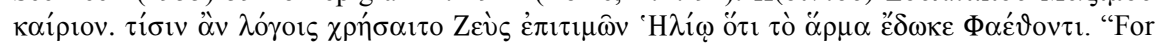
the death of Quintus Sulpicius Maximus. Which words would Zeus use to blame Helius for having given his chariot to Phaeton." The ethopeia itself is in hexameters, presumably a school exercise, since they were composed by a boy eleven years old. POxy. IV 671 (Oxyrhynchus, late

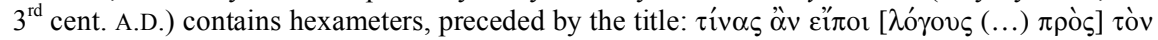
v[i]ò̀ $\tau$ ov $\Delta \varepsilon$ [ "Which words would (...) use towards the son of De-." On ethopeia in Greek poetry of the Roman Empire, see Agosti (2005); on ethopeia in verse found in papyri, see Fernández (1994).

27 See Wifstrand (1933) $150 \mathrm{n} .1$.

28 See D'Ippolito (2002) 240-243; Vian (1990) 158-159. This is not the only passage where Athens appears in the Dionysiaca: in Nonn. D. 13.171-200, the poet also lists a few towns of Attica which are sending soldiers to fight along with Dionysus. See Chuvin (1991) 47-53. 
Hellenistic period, but it made a remarkable comeback during the Empire, thanks to the movement we call the Second Sophistic. ${ }^{29}$ Although the Greek cities of the Empire could not seriously hope to restore the past glory of Athens, they nevertheless turned it into a kind of myth, which was appropriated not only by the Greeks, but also by the Romans. The verses of Panteleus on the battle of Marathon in a way prolonged what had been the Roman ideology since the reign of Augustus: the Parthian threat against the Roman empire was equated to the Persian attack on Greece five centuries earlier. ${ }^{30}$ The Athenian victory over the invader was therefore not incompatible with Rome's interests.

Leaving the historical and strategic perspective aside and coming back to a literary evaluation of Panteleus' verses, we can observe that several genres which had had a distinct identity in the past now join in this ethopeia. By its form, the verses clearly belong to the epic genre, with the use of hexameters and Homeric

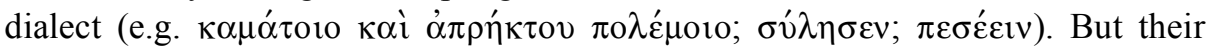

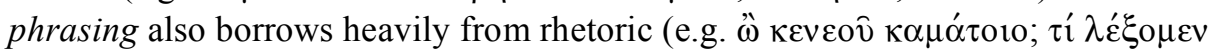

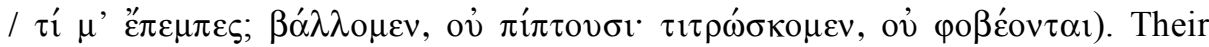
contents on the other hand correspond neither to traditional epic nor to rhetoric, but to historiography, with the account of the Athenian victory over the Persians in Marathon. Even if Aristotle in the fourth century B.C. could envisage boundaries between different literary genres, such distinctions are no longer valid in the Roman period. This provides us with the background against which we can now evaluate Quintus' treatment of one particular episode, that of the rescue of Aethra.

\section{Aethra Rescued by her Grandsons}

Book 13 of the Posthomerica is devoted to the sack of Troy, itself divided into several episodes. The reader must reach almost the end of the book to find the story of Aethra, who is recognized by her grandsons Acamas and Demophon.

29 The term 'Second Sophistic' was coined by Philostratus in the early third century A.D., but he does not give it the same meaning as modern scholarship does. For Philostratus (Vitae Sophistarum p. 481 Olearius), the First Sophistic started with Gorgias, whereas the Second Sophistic was founded by Aeschines. In other words, both the First and the Second Sophistic are to be dated - in Philostratus' mind - to what we now call the Classical period. The sophists of the Roman Empire were discussed at great length by Philostratus in his Lives of the Sophists, but he does not give a specific name to the movement which modern scholarship now calls the Second Sophistic.

30 See Spawforth (1994). 


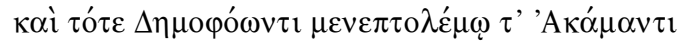

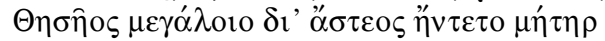

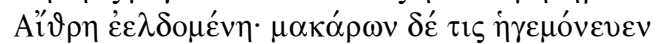

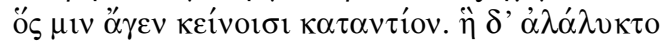

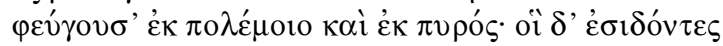

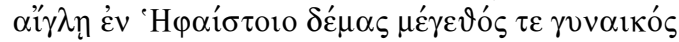

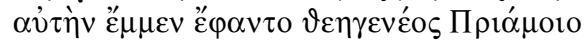

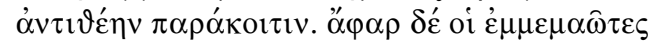

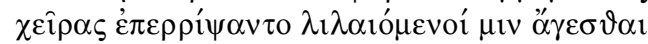

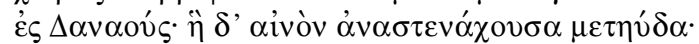

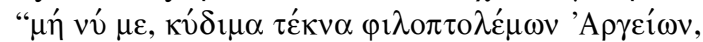

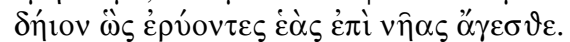

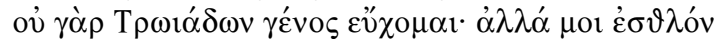

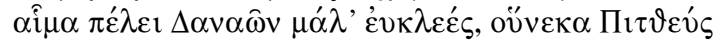

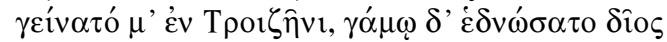

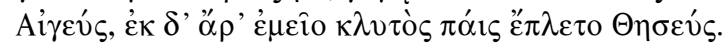

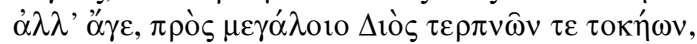

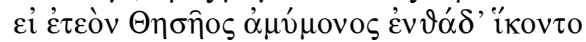

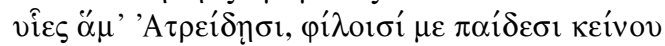

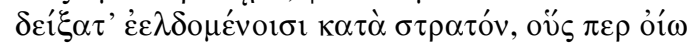

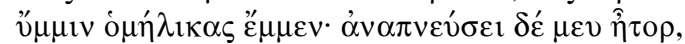

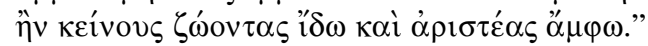

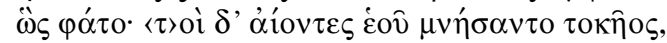

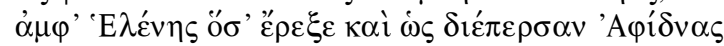

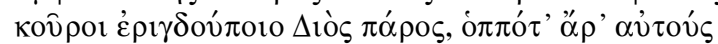

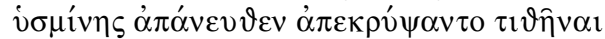

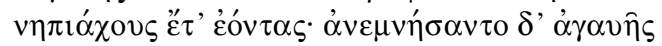

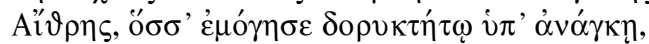

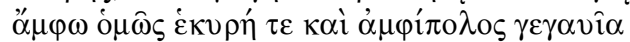

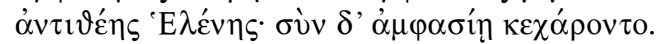

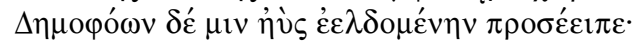

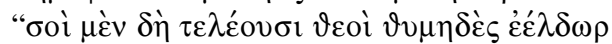

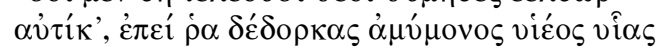

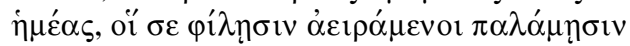

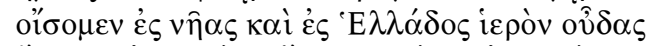

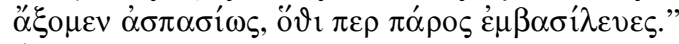

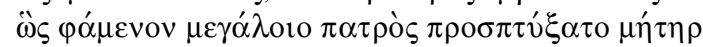

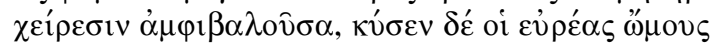

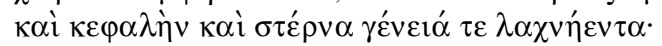

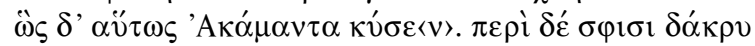

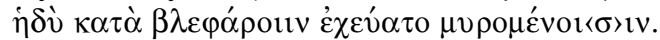

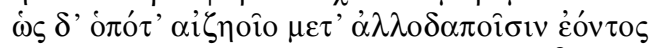

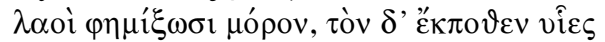

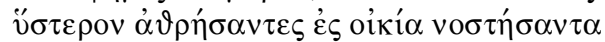

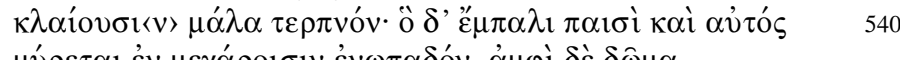

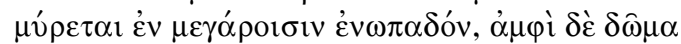

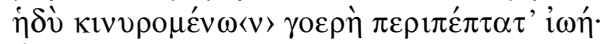

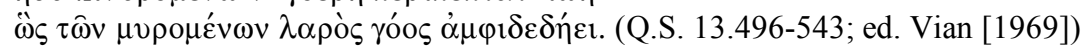


Then Aethra met valiant Demophon and Acamas,

the sons of great Theseus, who were looking

for her in the city. It was a god

who led her and put her on their path. She was distressed

as she fled from war and arson. When they saw her

in the light of Hephaistus, judging from the appearance and size of the woman, they would have said she was the divine spouse of Priam,

offspring of the gods. Full of fury,

they laid hands on her, striving to take her

to the Danaeans. But she wailed horribly and said:

"Do not, glorious children of the war-loving Argians, take me to your ships like an enemy.

I do not claim Trojan ancestry: for I am of the noble

and most glorious blood of the Danaeans, since Pittheus

begat me in Troezen. Divine Aegeus took me

as his wife, and I gave him glorious Theseus for a son.

But please, for the sake of great Zeus and of your dear parents,

if truly the sons of blameless Theseus have come here together

with the Atrids, show me to [Theseus'] children,

since they are looking for me within the army. I believe that they

are of the same age as you. My heart will breathe again

if I see them both alive and in good shape."

Thus she spoke, and they heard her, remembering their father's deeds, what he had done to conquer Helen, and how the Dioscuri,

sons of thundering Zeus, had in the past destroyed Aphidnai: they were still

babies, and their nurses had hidden them away

from the battle. They remembered noble Aethra,

and how she had toiled under the constraints of her condition as a prisoner of war,

having become the mother-in-law as well as the servant

of divine Helen. Their joy was such that they could not speak.

Demophon, however, addressed his much sought-after [grandmother]:

"The gods have just fulfilled your dearest desire,

for by looking at us you have set eyes upon the children

of your excellent son; we will carry you with our hands

to our ships, and will take you gladly to the sacred land of Greece,

the same land where you were queen in the past."

Thus he spoke, and the mother of his great father embraced him,

kissing his broad shoulders,

his head, his chest and his bearded cheeks.

In the same fashion did she kiss also Acamas. And while they wept

their eyes shed sweet tears.

When people report the death of a brave man

tarrying abroad, and his sons later see him

come back home from some place or other,

they break into pleasurable weeping. And he in turn sobs

in the face of his children at home, while the house

echoes of the lamenting cries of a sweet mourning;

such was the enjoyable grief that seized them as they lamented. 
In short, Acamas and Demophon seize Aethra and mistake her for Hecuba (13.496-505). Failing to recognize the two young men, Aethra addresses them a supplication in which she states her genealogy and enjoins them to help her find her grandsons (505-517). Acamas and Demophon remember that Aethra was Helen's mother-in-law as well as her servant (518-525). Demophon recognizes Aethra (526-531). Grandmother and grandsons are reunited (532-543). In the following verses (544-551), Quintus relates how Laodice, one of Hecuba's daughters, was swallowed up by the earth. Although this last episode is not openly linked to the story of Acamas and Demophon, we shall see that it does in fact belong to the same narrative.

To fully understand the link between Aethra and Hecuba, one must first remember that Theseus, with the help of Pirithous, had abducted Helen before her marriage to Menelaus. ${ }^{31} \mathrm{He}$ entrusted his mother Aethra with Helen while he was going down to Hades in order to abduct Persephone on behalf of his companion Pirithous. Meanwhile, the Dioscuri reclaimed Helen and in their turn abducted Aethra, who thus became the servant of Helen. ${ }^{32}$ When the latter followed Paris to Troy, Aethra went with her and endured a second captivity. Aethra is already mentioned as Helen's servant in Troy in the Iliad (3.144).

The role of Aethra's grandson, Acamas, is neatly summarized in a passage from the scholia to Lycophron.

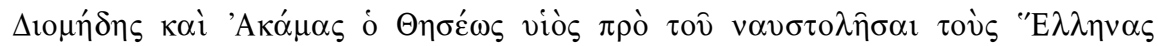

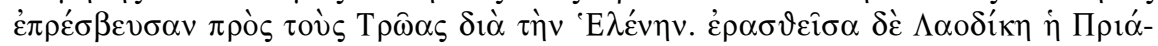

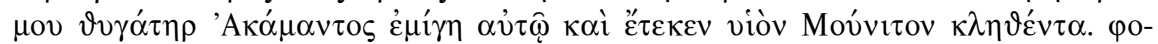

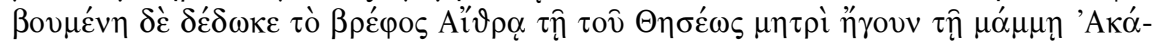

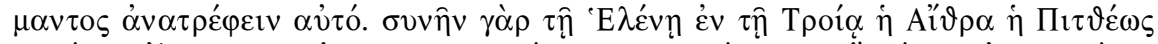

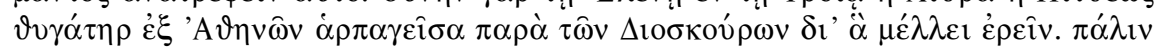

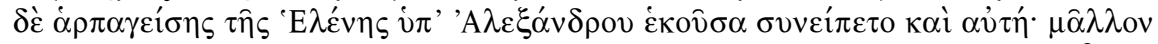

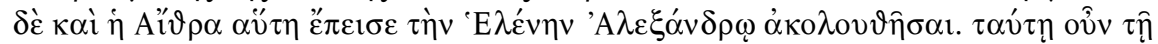

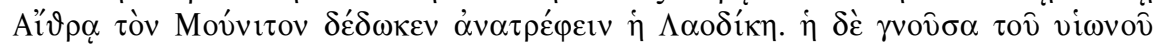

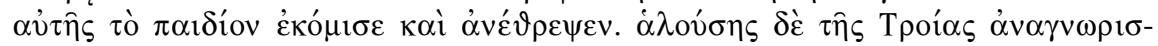

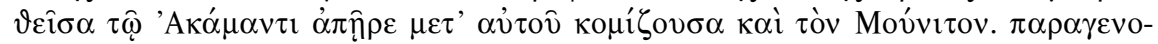

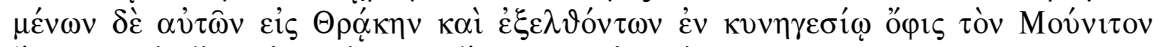

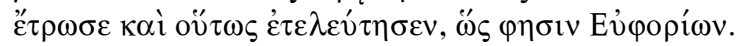

(schol. on Lyc. 495; ed. Scheer [1908])

Before the Greek expedition, Diomedes and Acamas, son of Theseus, were sent on an embassy to Troy in order to claim Helen. Laodice, daughter of Priam, fell in love with Acamas; she made love with him and bore him a son called Munitus. She was however scared, and gave the baby to Aethra, the mother of Theseus - in other words the grandmother of Acamas -, asking her to raise the child. For Aethra, the daughter of

31 See Clader (1976) 71-72.

32 Pseudo-Apollodorus 3.10.7 and Epitome 1.23. 
Pittheus, was in Troy with Helen, having been abducted from Athens by the Dioscuri because of what she might reveal. When Helen was again abducted, this time by Alexander, Aethra followed her of her own will, or it was rather Aethra herself who persuaded Helen to follow Alexander. It was therefore that same Aethra whom Laodice entrusted with Munitus, asking her to raise him: once Laodice had learned that the boy was the son of Aethra's grandson, she passed him over to Aethra, who brought him up. At the fall of Troy, she was recognized by Acamas and left with him, taking along also Munitus. They went to Thracia and, while they were out hunting, a snake killed Munitus; this was the cause of his death, as recalled by Euphorion.

Munitus was thus born of a brief encounter between Acamas and Laodice. Since the mother could not keep the child without losing her honour, she had to entrust him to Aethra, who happened to be his great-grandmother!

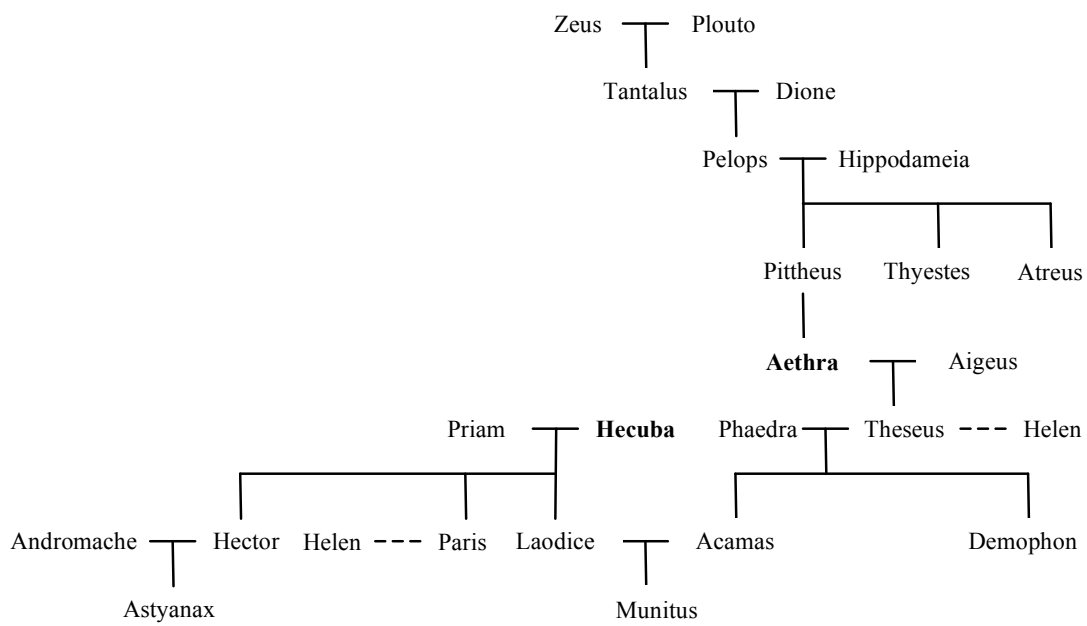

Quintus seems to have followed here the story told by Lycophron in his Alexandra. ${ }^{33}$ The sudden transition between the story of Aethra and that of Laodice is not so surprising after all.

At the fall of Troy, the brothers Acamas and Demophon are faced with an old woman whom they mistake for Hecuba (13.500-503): "When they saw her in the light of Hephaistus, judging from her appearance and size, they would have said she was the divine spouse of Priam, offspring of the gods." Acamas and Demophon want to seize her and take her to the camp as a prisoner of war, but Aethra, without naming herself explicitly, states her genealogy, and the two brothers recognize their grandmother.

33 See Vian (1969) 123-124. 


\section{The Fall of Troy and the Rise of Athens (but where is Rome?)}

The episode of Aethra could be taken as a mere quid pro quo, a mistaken identity that is quickly corrected. But a look at the family tree suggests that there is more to that story than a similitude in the physical appearance of two characters. Theseus (Aethra's son) and Paris (Hecuba's son) had both abducted Helen; in other words, both Aethra and Hecuba were forced to become Helen's mother-inlaw. But this resemblance serves only to underscore the contrast in the destiny of the two elderly women. Hecuba loses her husband as well as all her children, and is taken away as a captive; her grandson Astyanax is hurled from the top of the walls of Troy (13.251-252). Aethra, as we have just seen, raises her greatgrandson Munitus, and she is rescued by her two grandsons, who take her safely back home. ${ }^{34}$

Even more importantly, behind Hecuba and Aethra stand also two cities: Troy is destroyed, but Athens is on the rise. In other words, the parallel between Hecuba and Aethra also marks the transition from Troy to Athens. Aethra's son, Theseus, is considered as the mythical founder of the Athenian city-state, and Acamas gave his name to the Acamantid tribe in Athens. ${ }^{35}$ A passage from Pseudo-Demosthenes' Funeral Oration is quite explicit on the matter: ${ }^{36}$

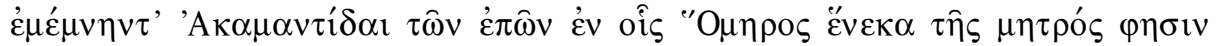

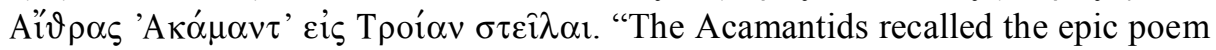
in which Homer says that Acamas sailed to Troy for the sake of his mother [sic]."

How does such an interpretation fit in the more general context of the Posthomerica? In other words, can we extend it to the understanding of the whole poem, and is it plausible that Quintus would oppose here Athens to Troy, instead of following the trodden path of a transition from Troy to Rome? ${ }^{37}$

In general terms, there is no doubt that Quintus acknowledges the supremacy of Rome. We only have to remember Calchas' prophecy, where he announces the bright future of Rome (13.334-341): Aeneas will move to a new place, where his descendants will establish their dominion over the peoples of the East and of the

34 This aspect of the story was clearly already present in Arctinus' Iliupersis, see Iliupersis (Ilii

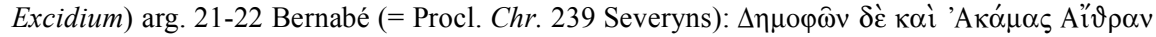

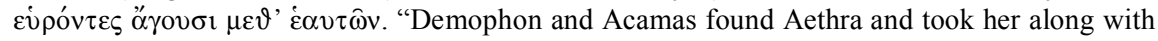
them."

35 Theseus: Isocrates, Helena 35-36; Plutarch, Theseus 24.1-3; on Acamas, see Kearns (1989) 143144.

36 [Dem.] 60.29, see Bernabé ( ${ }^{2}$ 1996) 92 on Iliupersis (Ilii Excidium) fr. 6 and Iliupersis fr. 6 West (2003).

37 On this question, see also Hadjittofi in this volume. 
West. ${ }^{38}$ Therefore the story of Aethra, when it is set against the background of Calchas' prophecy, becomes even more singular.

At the Hellenistic period, while the Romans were laying hands on Greece, Athens' position towards Rome was somewhat different. An example of it can be found in an epigram ascribed to Polystratus, a poet from the second century B.C. ${ }^{39}$

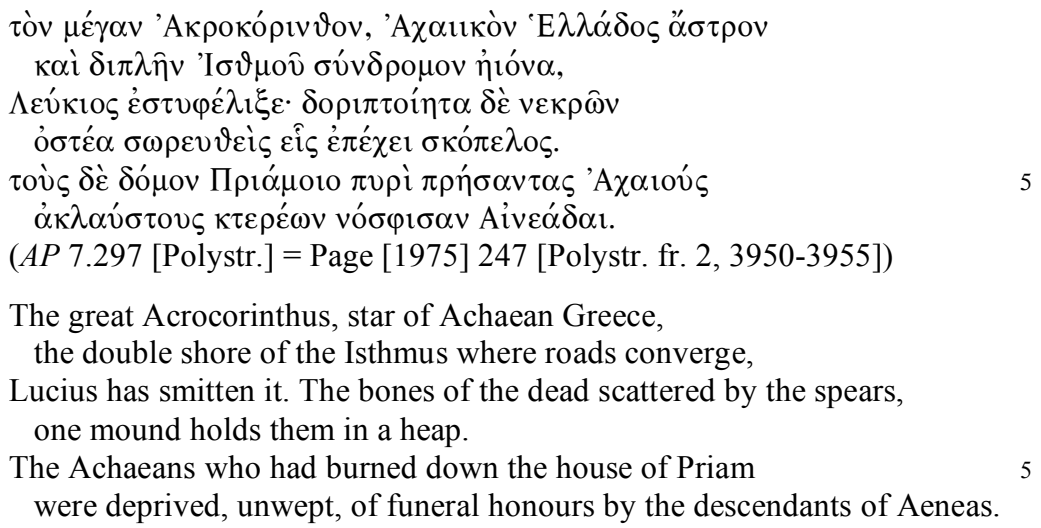

In this epigram, the Romans are closely linked to the Trojans through Aeneas. The sack of Corinth took place in 146 B.C. under the command of the Roman general Lucius Mummius. Here, the Greeks first strike Troy, then have to suffer destruction by the hands of the Romans, who are presented as the heirs of the Trojans. We can thus discern a move from Troy to Greece to Rome.

In the Augustan period, Dionysius of Halicarnassus argues - at the beginning of his Antiquitates Romanae - that Rome is in fact a Greek city. If we turn to the Roman Empire, Dio of Prusa acknowledges in his - admittedly paradoxical -

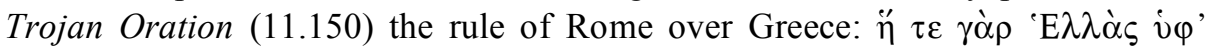

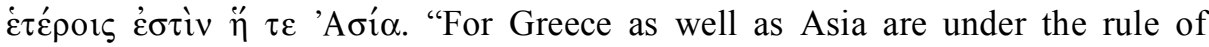
others." He also follows the usual pattern of a transfer of power from Troy to Rome:

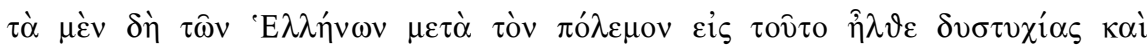

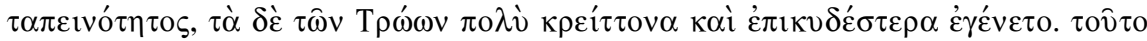

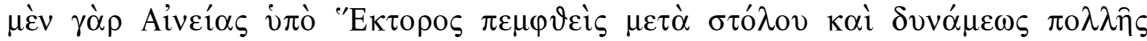

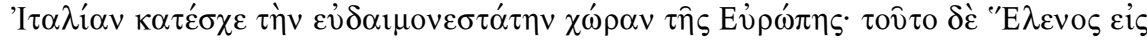

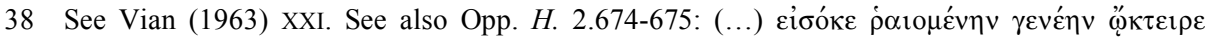

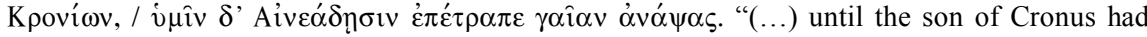
mercy on the afflicted race and entrusted you, the descendants of Aeneas, with the whole earth." The same idea is present also in Nonn. D. 3.189, 3.428, 41.365, and 41.389-391.

39 On the dating of Polystratus, see Gow / Page (1965) 480. 


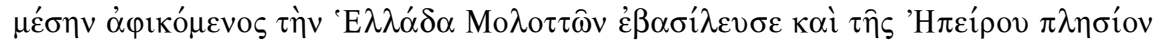

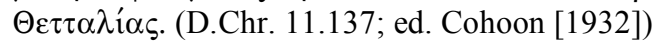

After the war, the Greeks met with such misfortune and humiliation, while the Trojans acquired much more power and glory. On the one hand, Aeneas was sent by Hector with a fleet and a large army, and seized Italy, the most blessed country in Europe; on the other, Helenus reached central Greece where he ruled over the Molossians and Epirus near Thessaly.

On the whole, Dio's view concords with the line accepted since the reign of Augustus. ${ }^{40}$ Quintus follows Polystratus and Dio inasmuch as he clearly recognizes Roman rule. In telling the story of Aethra, however, he has introduced a new dimension by suggesting a movement from Troy to Athens, without taking Rome into account. He clearly did not intend to produce an epic poem that could rival Virgil's Aeneis. Nevertheless, in drawing a parallel between Hecuba and Aethra, he is suggesting - at least implicitly - a response to the main theme of the Latin epic poet: Aeneas leaves Troy after its collapse and reaches Italy, where a new civilisation can emerge from the union of a local and an imported element. Thus Troy disappears but makes place for Rome. Under the reign of Augustus, the poet not only asserted the prince's claim to power, but also united the Latin and Greek halves of the Mediterranean in the story of a Trojan who had migrated to the West. Such is also the vision conveyed by Calchas' prophecy.

When Quintus composed his Posthomerica more than two centuries after Virgil, however, the political situation had considerably changed. What he could write then may not have been possible under the hand of Virgil, but also of Horace, or even of Dionysius of Halicarnassus. Cities of Asia Minor were flourishing again, partly through the help of emperors who came from the West, but embraced the cause of Hellenism. Hadrian, then Antoninus and Marcus Aurelius, can be counted among the strongest supporters of the eastern cities, notably Ephesus, Smyrna, Miletus, Pergamon, and of course Athens. Even the equation between Parthians and Persians, which had been in continuous use with the emperors during the first century, had lost some of its relevance when the Parthians became less menacing in the second century. ${ }^{41}$

We saw that, in the context of the Second Sophistic, Athens gains a new prominence as the model par excellence for all those who want to display eloquence, learning and education. Through the example of Panteleus' short poem, it was also shown that Athenian history, transformed into a form of mythology, could be included into the epics, at least from a formal point of view. It seems

40 On the relation between Rome and Greece in the early Roman Empire, see esp. Swain (1996) 65-79.

41 See Spawforth (1994) 242-243. 
difficult to imagine that, even at the time of Quintus, someone could remodel the epic tradition so as to give to Athens a role comparable with that of Rome in the Aeneis; this would be a pointless and futile move. One could nevertheless easily conceive of a poet who, under the strong influence of the Athenian model in many aspects of literature, would choose to follow in one passage a tradition linking Troy, albeit indirectly, to Athens. 
